\title{
DYNAMICS OF HISTOLOGICAL CHANGES IN THE SKIN OF RATS 1, 3, 7, 14, 21 AND 30 DAYS AFTER BURNS OF II-III DEGREE AGAINST THE BACKGROUND OF THE INTRODUCTION OF THE FIRST 7 DAYS OF HAES-LX-5 \% SOLUTION
}

\author{
Mironov Yevheniy Viktorovych, Postgraduate student \\ National Pirogov Memorial Medical University, Vinnytsya, Ukraine
}

DOI: https://doi.org/10.31435/rsglobal_ws/30042020/7017

\section{ARTICLE INFO}

Received: 12 February 2020

Accepted: 16 April 2020

Published: 30 April 2020

\section{KEYWORDS}

skin burns,

histological changes, endothelial cells,

HAES-LX-5 \% solution.

\begin{abstract}
The article presents the results of studies of histological changes in the skin of rats in different periods after burn injury $(1,3,7,14,21$ and 30 days) with an area of 21-23\% of the body surface of II-III degree on the background of intravenous injection of the first 7 days of HAES LX-5\% solution at a dose of $10 \mathrm{ml} / \mathrm{kg}$. From the $1 \mathrm{st}$ to the $3 \mathrm{rd}$ day of the experiment, it was found that the condition of the structural components of the skin was close to that of animals treated with an intravenous first 7 days of $0.9 \% \mathrm{NaCL}$ solution. The positive effect of HAES-LX-5 \% corrective solution infusion was observed from day 7 of the study. It is revealed that the drug significantly reduces dystrophic and necrobiotic processes in the epidermis, stimulates neoangiogenesis, has an antiswelling and protective effect on the endothelium of the blood vessels.
\end{abstract}

Citation: Mironov Yevheniy Viktorovych. (2020) Dynamics of Histological Changes in the Skin of Rats 1, 3, 7, 14, 21 and 30 Days After Burns of II-III Degree Against the Background of the Introduction of the First 7 Days of Haes-Lx-5 \% Solution. World Science. 4(56), Vol.1. doi: 10.31435/rsglobal_ws/30042020/7017

Copyright: (C) 2020 Mironov Yevheniy Viktorovych. This is an open-access article distributed under the terms of the Creative Commons Attribution License (CC BY). The use, distribution or reproduction in other forums is permitted, provided the original author(s) or licensor are credited and that the original publication in this journal is cited, in accordance with accepted academic practice. No use, distribution or reproduction is permitted which does not comply with these terms.

Introduction. Despite the wide variety of means and approaches to the treatment of burn disease, the problem of infusion therapy is always relevant. Infusion transfusion therapy in the first hours after thermal trauma is a key component in the treatment of burn shock [1,2]. At the same time, the faster the processes of microcirculation will be restored, the less chance for the occurrence of multiple organ failure syndrome. However, resuscitation therapy is not really an easy task, since failure to comply with certain conditions can have a negative impact on the course of burn disease [3,4]. The effectiveness of targeted individualized burn shock infusion therapy depends largely on the choice of solution. Studies have focused on the effect of infusion of HAES-LX-5\% solution on the treatment of the effects of burn disease, have proven its positive effect on the structure and function of vital organs, as well as the ability of this drug to fight metabolic intoxication syndrome [5, 6]. Infusion of HAES-LX-5\% solution causes an increase in osmotic blood pressure, increased evacuation of fluid from tissues into the vascular bed, restoration of hemodynamic disorders, improvement of blood circulation and rheological properties, increased cardiac activity, metabolic processes and improvement of liver detoxification function [7].

To date, many methods have been developed by scientists to treat the effects of thermal trauma of the skin and their significant effectiveness has been proven. Due to a large number of experimental studies, knowledge on the pathogenesis of burn shock has been significantly expanded. New drugs for the infusion therapy of the acute period of burn disease have been developed and have significant evidence base for their positive effect for the correction of metabolic disorders and restoration of normal functioning of all organs and systems $[8,9,10,11]$. However, the question of the 
influence of various infusion preparations on the processes occurring in the burn wound remains relevant today. Since it is the wound burn defect of the skin that is the trigger that subsequently triggers the systemic response of the body, it is extremely important to study the effect of infusion solutions on numerous pathomorphological changes in burned skin.

The purpose of the study is to study the features of histological changes in the skin of rats in different periods after burns of II-III degree against the background of the introduction of the first 7 days of HAES-LX-5 \% solution.

Material and methods of research. Studies were performed on 360 laboratory white male rats weighing $155-160 \mathrm{~g}$. In the course of the experiment, the animals were divided into 4 groups: 1 st, 2 nd groups - rats without thermal trauma infused with $0.9 \% \mathrm{NaCl}$ solution and HAES-LX-5\% at a dose of $10 \mathrm{ml} / \mathrm{kg}$. In the 3rd, 4th groups, rats were infused with $0.9 \% \mathrm{NaCl}$ solution and HAES-LX-5\% at 10 $\mathrm{ml} / \mathrm{kg}$ after skin burn. All experiments were carried out in accordance with the recommendations of the European Commission on the conduct of animal-biological studies with animals and the medical recommendations of the State Pharmacological Center of the Ministry of Health of Ukraine and "Rules for Clinical Safety Assessment of Pharmacological Products (GLP)" [12] and rules for the humane treatment of experimental animals (approved by Committee on Bioethics of National Pirogov Memorial Medical University, Vinnytsya - Protocol No. 1 dated January 14, 2010 and Protocol No. 1 dated January 18, 2018). Burning skin damage was caused by applying to the pre-depilated lateral surfaces of the trunk of rats for 10 seconds four copper plates (two plates on each side, each with a surface area of $13.86 \mathrm{~cm}^{2}$ ), which were pre-heated for 6 minutes in water with constant temperature $100{ }^{\circ} \mathrm{C}[13,14]$. The total area of skin lesion in rats was $21-23 \%$. All solutions were introduced into the inferior vena cava after catheterization under aseptic conditions through a femoral vein at a dose of $10 \mathrm{ml} / \mathrm{kg}$ body weight of the animal. Shaving of the lateral surfaces of rats' trunk, catheterization of veins, staging of skin burns, and decapitation of animals were performed under intravenous propofol anesthesia (calculated at $60 \mathrm{mg} / \mathrm{kg}$ body weight). For further in-depth study, we selected skin changes at 1, 3, and 7, 14 21, and 30 days from the start of the experiment. For histological examination, skin fragments were fixed in $10 \%$ neutral formalin solution, washed in running water, dehydrated in a battery of alcoholic solutions of increasing concentration, and enclosed in a steamer [15]. Sections 4-6 $\mu \mathrm{m}$ thick were made on a rotary microtome, placed on slides, stained with eosin hematoxylin after standard wiring, and poured into Canadian balm. Histological specimens were examined in an OLYMPUS BH-2 light microscope using $\times 10$ and $\times 40$ lenses and an $x 10$ eyepiece.

Results and discussion. Histologically, it was found that in the early period after burns $(1,3$ days) in rats intravenously injected with HAES-LX-5\% solution, the skin condition was close to that in animals administered $0.9 \% \mathrm{NaCl}$ solution. The epidermis and papilla of the dermis are necroticly altered. Necrotic masses in the defect area and leukocyte infiltration are distributed to the deep layers of the dermis (Fig. 1).

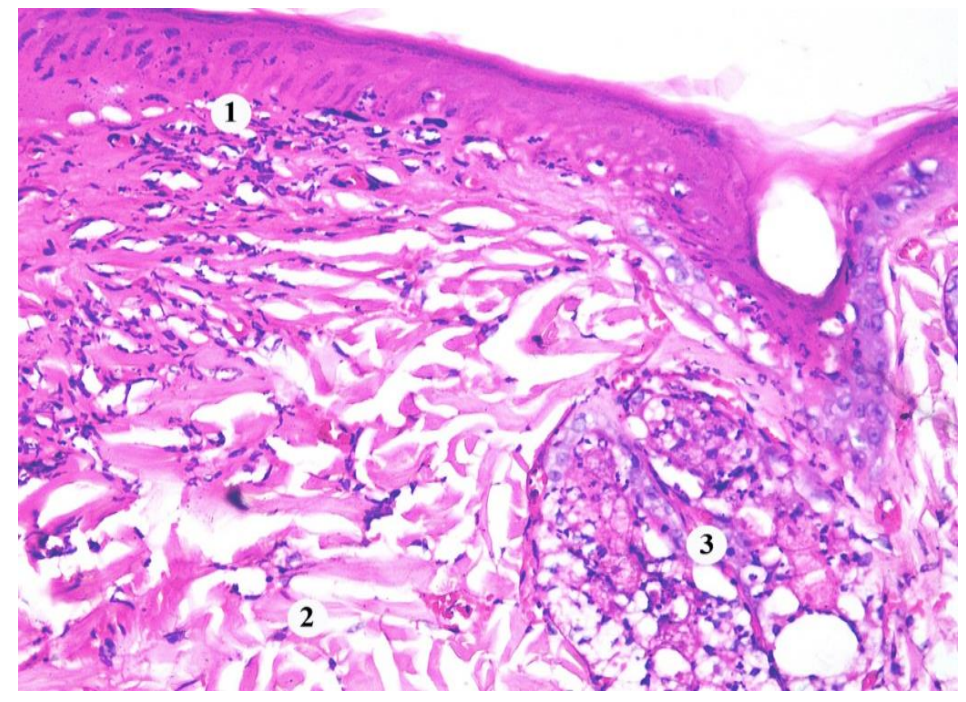

Fig. 1. Histological changes in the skin of the rat at 1 day after burn with the introduction of HAESLX-5\%: 1 -necrotized epidermis and dermis, 2 - collagen fibers, 3 -destructively altered skin appendages. Staining with hematoxylin and eosin. $\times 200$. 
The blood vessels of the microcirculatory bed are enlarged and full-blooded with the phenomena of stasis, thrombosis and adhesion of leukocytes to the endothelium. The endothelial cells in the walls of the blood vessels are destructively altered, foci desquamated. Hemorrhages were found around the vessels (Fig. 2).

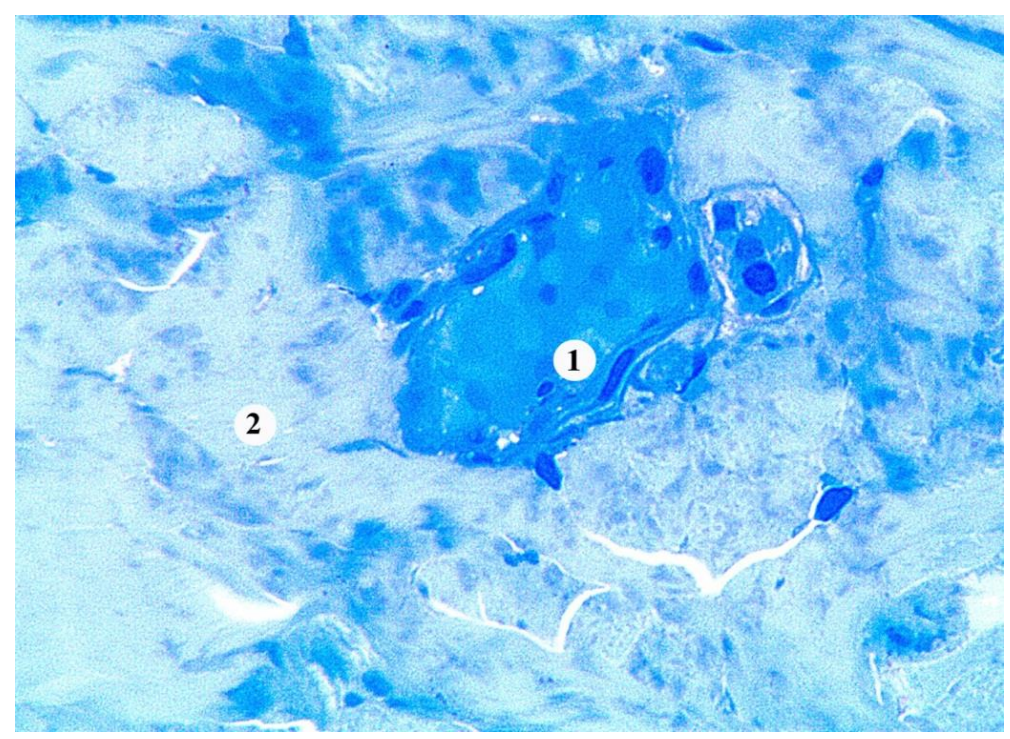

Fig. 2. Microscopic changes in the skin dermis of the rats for 3 days after burn, with the introduction of HAES-LX-5\%: 1 - hemostasis in venules, 2 - coagulated and swollen collagen fibers. Semi-thin section. Methylene blue staining. $\times 400$.

On the 7th day of the experiment, under the conditions of correction, the presence of a scab formed from the destroyed blood cells, epidermocytes and fibrin is observed. The crust does not go far beyond the damage and covers a somewhat thickened layer of epithelium at the periphery of the wound. The epithelial regenerate, located under the scab is not continuous, thin, consists of one or three layers of focally located keratinocytes (Fig. 3).

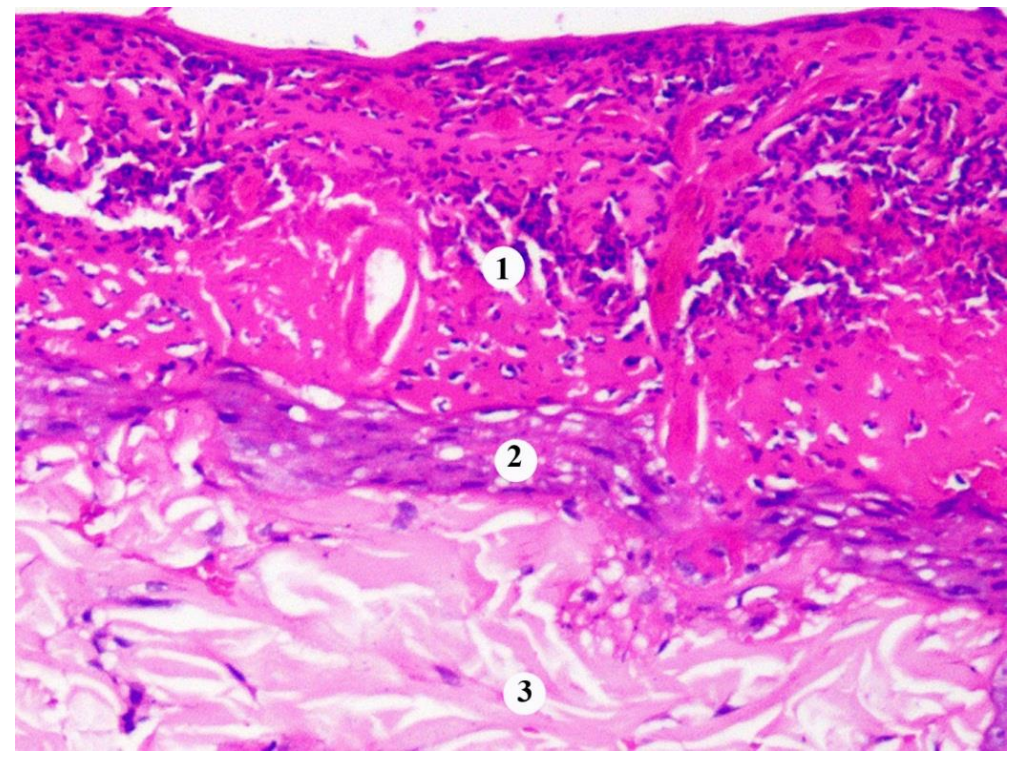

Fig. 3. Histological changes in the central area of the wound of the skin of the rat for 7 days after burn, with the introduction of HAES-LX-5\%: 1 -scab, 2 - epithelial regenerate, 3 -dermis. Staining with hematoxylin and eosin. $\times 400$.

In the marginal area of the wound, which is free from the crust, the epithelial layer is hypertrophied and cells in the mitotic division are observed. Hemorrhage is present in the connective tissue of the papillary layer of the perifocal area of the wound (Fig. 4). 


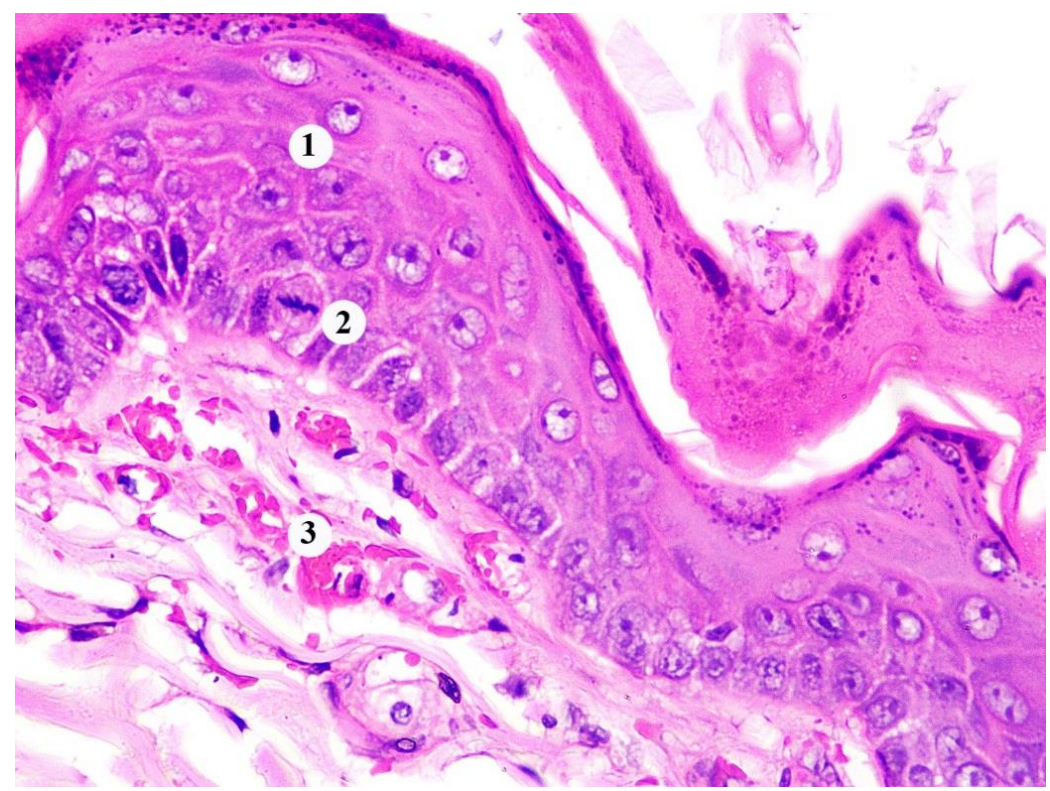

Fig. 4. Histological changes in the marginal area of the wound of the skin of the rat at 7 days after burn, with the introduction of HAES-LX-5\%: 1-thickened area of the epidermis, 2 - keratinocyte in the stage of metaphase of mitosis, 3 - hemorrhage. Staining with hematoxylin and eosin. $\times 400$.

The process of reparative regeneration involves preserved hair follicles whose epitheliocytes actively proliferate. The dermal edema at the center of the lesion and leukocyte infiltration was microscopically detected, but it was less pronounced compared to the control group of animals. The composition of leukocyte infiltrates was dominated by histiocytes, as well as lymphocytes and plasmocytes. The lumen of the capillaries of the mesh layer of the dermis is slightly expanded (Fig. 5).

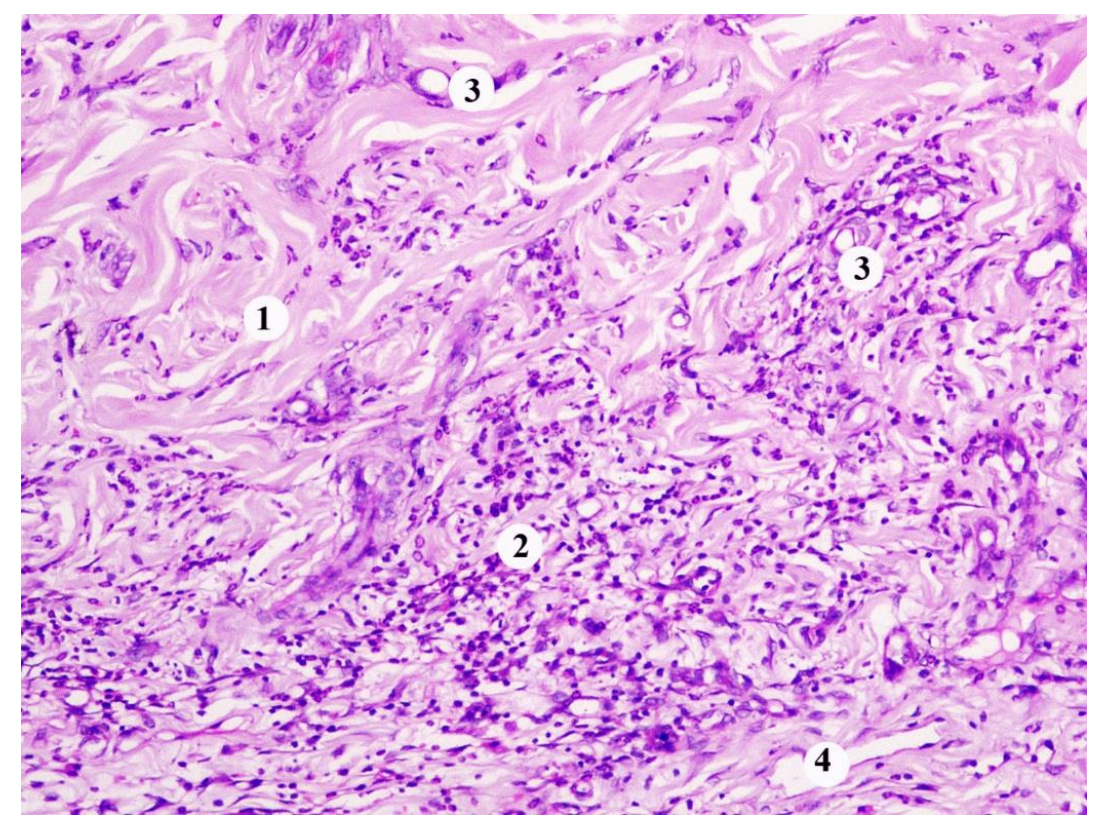

Fig. 5. Histological changes of the dermis of the central area of the wound of the skin of the rat for 7 days after burn, with the introduction of HAES-LX-5\%: 1 - collagen fibers, 2 - leukocyte infiltration,

3 - blood capillaries, 4 - lymphatic capillary. Staining with hematoxylin and eosin. $\times 200$.

Histologically, on the 14th day of the experiment, when the correction factor is applied, detachment of the scab from the wound surface is observed. Under the scab there is a regeneration zone in the form of an epithelial coating and a wide layer of ripening granulation tissue, which is rich in cells of the leukocyte row, fibroblasts, fibrous structures, blood capillaries. Skin appendages were not detected in the wound area (Fig. 6). 


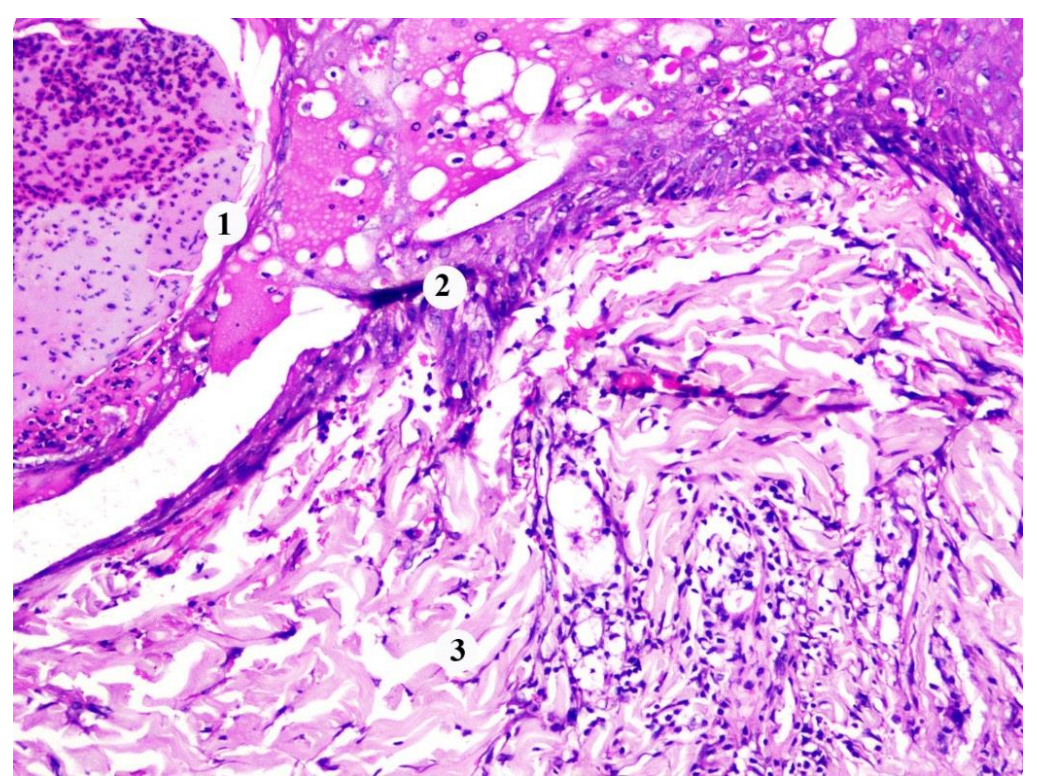

Fig. 6. Histological changes of the dermis of the central area of the wound of the skin of the rat for 14 days after burn, with the introduction of HAES-LX-5\%: 1 - scab, 2 - epithelial regenerate, 3 dermis. Staining with hematoxylin and eosin. $\times 200$.

Microscopically, it was found that for 21 days of the experiment after thermal trauma, when applying the correcting factor, the lesion area covers a multilayered flat corneal epithelium with a clear structural layered organization. In the basal layer, epidermocytes with figures of mitosis were detected, their number was greater than that in control rats. On the surface of the epidermal regenerate a thin layer of epidermal scales is observed. Basal membrane of uneven thickness, below it there are collagen fibers and small hemorrhages. The formation of skin appendages is observed (Fig. 7).

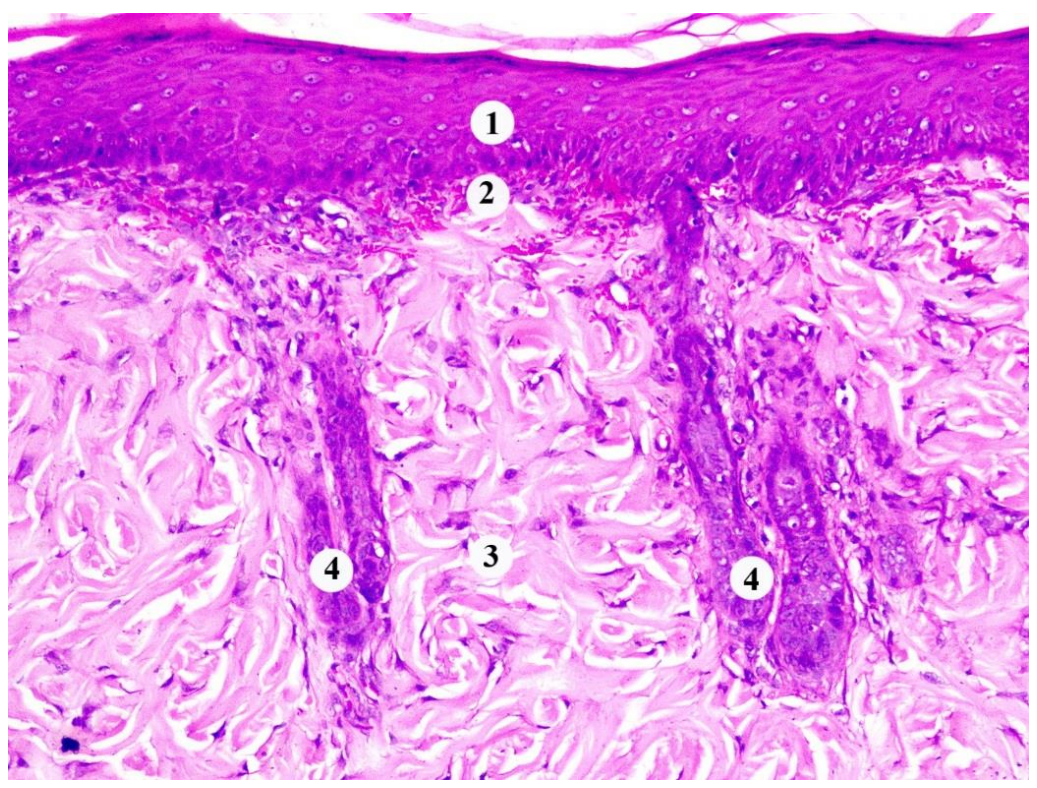

Fig. 7. Histological changes in the area of healing of rat skin for 21 days after burn, with the introduction of HAES-LX-5\%: 1 - epidermis, 2 - hemorrhage, 3 - mesh layer of the dermis, $4-$ formation of appendages. Staining with hematoxylin and eosin. $\times 200$.

During this period, studies in the marginal area also revealed signs of formation of the papillary layer of the dermis. In the epidermis grows shallow outgrowths of loose connective tissue that contained blood capillaries. The latter had a small, moderately full-blooded lumen. The endothelial cells in the walls of the blood capillaries formed a continuous layer, had elongated nuclei. Perivascular spaces are not enlarged, indicating that there is no swelling of the intercellular substance of the loose connective tissue. 
On the 30th day of the experiment of intravenous administration of HAES-LX-5 \% in animals observed healing of the lesion with restoration of the integrity of the skin. The formed epidermis, papillary and mesh layers of the dermis are microscopically present (Fig. 8).

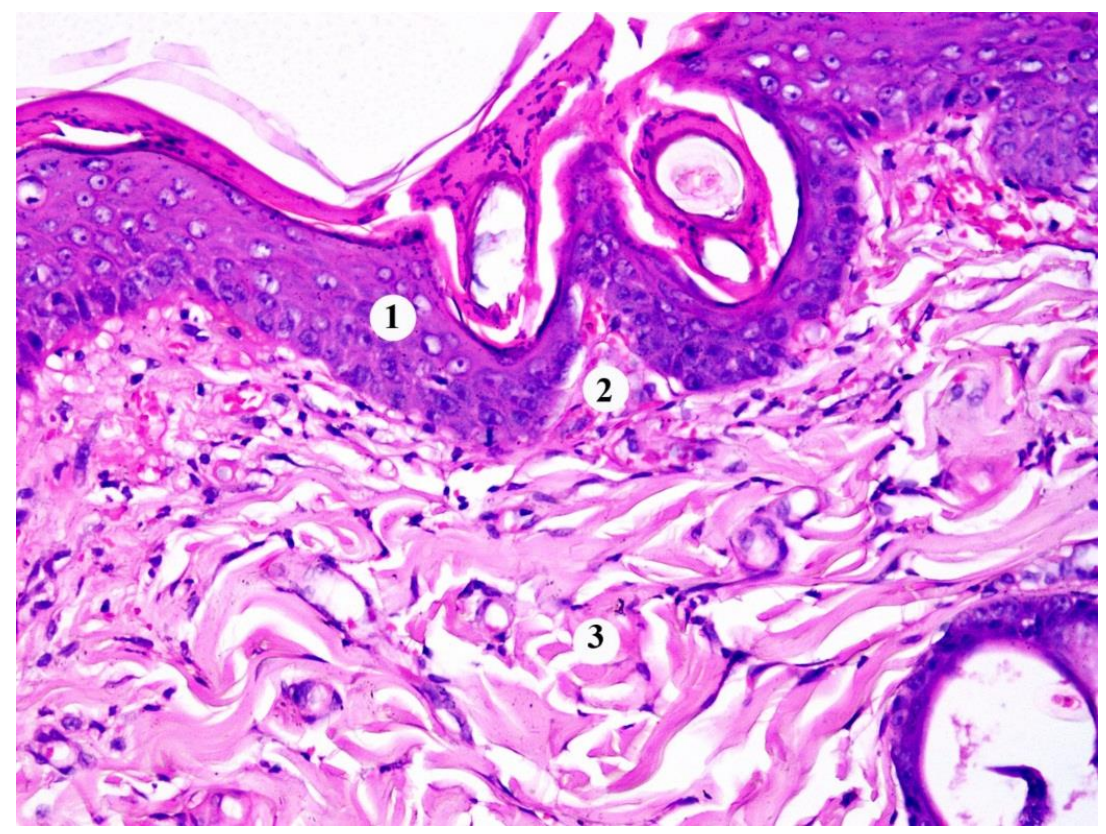

Fig. 8. Histological condition of the skin healing area of the rat for 30 days after burn, with the introduction of HAES-LX-5\%: 1 - epidermis, 2 - papilla of the dermis, 3 - mesh layer of the dermis. Staining with hematoxylin and eosin. $\times 200$.

The positive effect of the infusion of the correction solution HAES-LX-5\% on the peculiarities of the course of burn disease, established during the experiments, is associated with the data obtained by us during histological examinations. Dystrophic and destructive changes in the lungs were known to be less pronounced in rats treated with the HAES-LX-5\% solution than in those receiving $0.9 \% \mathrm{NaCl}$. The drug reduced the aggregation of platelets and erythrocytes in the blood vessels of the microcirculatory bed by 7 days after thermal trauma $[16,17]$. It was also established that the application of HAES-LX-5\% in the early period after skin burns positively affects the state of the structural components of the alveoli, the aerohematic barrier, increases the activity of secretory alveolocytes and alveolar macrophages [18].

Under the condition of administration to rats during the first 7 days of HAES-LX-5\% solution, the dystrophic and destructive changes in the structure of the stroma and parenchyma of the spleen were less pronounced compared to the animals of the control group and the experimental group receiving $0.9 \% \mathrm{NaCl}$ solution. The positive effect of the drug is due to a decrease in lymphocytolysis and atrophic processes, as well as stimulation of compensatory processes in the white pulp of the spleen. In addition, it was found that HAES-LX-5 \% has endothelial-protective properties, reduces the degree of manifestation of negative changes in the microcirculatory channel of the organ and reduces the aggregation capacity of platelets [19].

It has been established that this solution for the correction of the effects of burn disease activates the components of cellular and humoral immunity in the spleen for the 14th day of the study, causing an increase in the number of macrophages [20].

The morphological equivalent of the positive effect of HAES-LX-5\% is its distinct cytoprotective effect on the structure of the medulla of the kidneys. The latter is due to the induction of hypertrophy and hyperplasia of mitochondria, as well as the stimulation of mitophagy, which plays an extremely important role in the elimination of damaged organelles and inhibition of cell apoptosis [21].

Conclusions. During intravenous administration of HAES-LX-5 \% within 7 days after thermal skin injury, the dystrophic and necrobiotic processes in the epidermis and dermis were found to be less pronounced in the experimental animals than in the control group in the experimental animals. Positive dynamics of morphological changes of structural components of the skin, reduction of manifestations of alteration, neoangiogenesis, active marginal proliferation of epidermocytes when 
applying the correcting factor, which are most clearly manifested at 7 and 14 days of the experiment, associated with the property of HAES-LX-5\% to retain blood plasma in the blood vessels, which significantly reduces swelling, as well as the endothelial-protective effect of this drug.

\section{REFERENCES}

1. Guilabert, P., Usua, G., Martin, N., Abarca, L., Barret, J. P., \& Colomina, M. J. (2016). Fluid resuscitation management in patients with burns: update. Br J Anaesth, 117(3), 284-296.

2. Masood, R. A., Wain, Z. N., Tariq, R., Ullah, M. A., \& Bashir, I. (2016). Burn Cases, Their Management and Complications: A Review. International Current Pharmaceutical Journal, 5(12), 103-105.

3. Литовченко, А. Н., Цогоев, А. А., Григорьева, Т. Г., \& Олейник, Г. А. (2012). Инфузионная терапия ожогового шока - еще раз об известном. Медииина неотложных состояний, 4(43), 9-13.

4. Sanchez-Sanchez, M., Garcia-de-Lorenzo, A., \& Asensio, M. J. (2016). First resuscitation of critical burn patients: progresses and problems. Med Intensiva, 40(2), 118-124.

5. Козинець, Г. П., Осадча, О. І., Боярська, Г. М., Ісаєнко, Р. П., Солодкий, Ю. А., \& Шматова, О. О. (2014). Клінічна ефективність застосування препаратів гідроксиетилкрохмалю нового покоління у хворих з поширеними опіками при розвитку септичних ускладнень. Шпитальна хірургія, 3, 11-15.

6. Кондрацький, Б. О., Новак, В. Л., \& Кондрацький, Я. Б. (2015). Новий колоїдно-гіперосмолярний розчин HAES-LX-5 \% як засіб для малооб'ємної ресусцитації на догоспітальному етапі. Збірник наукових прачь співробітників НМАПО ім. П. Л. Шупика, 24(5), 132-137.

7. Aubran, C., \& Bellomo, R. (2013). Infusion of hydroxyethyl starch-containing fluids. Minerva Anaesthesiol, 79(9), 1088-1092.

8. Матвеев, С. Б., Смирнов, С. В., \& Тазина, Е. В. (2013). Динамика эндогенной интоксикации у пациентов с обширными ожогами. Клиническая лабораторная диагностика, 2, 10-12.

9. Bechir, M., Puhan, M. A., Fasshauer, M., Schuepbach, R. A., Stocker, R., \& Neff, T. A. (2013). Early fluid resuscitation with hydroxyethyl starch 130/0,4 (6\%) in severe burn injury: a randomized, controlled, double-blind clinical trial. Crit Care, 17(6), 1-8.

10. Perel, P., Roberts, I., \& Ker, K. (2013). Colloids versus crystalloids for fluid resuscitation in critically ill patients. Cochrane Database Syst Rev, 28(2), CD000567.

11. Soussi, S., Depret, F., Benyamina, M., \& Legrand, M. (2018). Early Hemodynamic Management of Critically III Burn Patients. Anesthesiology, 129(3), 583-589.

12. Добреля, Н. В., Бойцова, Л. В., \& Данова, І. В. (2015). Правова база для проведення етичної експертизи доклінічних досліджень лікарських засобів з використанням лабораторних тварин. Фармакологія та лікарська токсикологія, 2, 95-100.

13. Gunas, I., Dovgan, I., \& Masur, O. (1997). Method of thermal burn trauma correction by means of cryoinfluence. Abstracts are presented in zusammen mit der Polish Anatomical Society with the participation of the Association des Anatomistes Verhandlungen der Anatomischen Gesellschaft, Olsztyn (p. 105). Jena - München: Der Urban \& Fischer Verlag.

14. Regas, F. C., \& Ehrlich, H. P. (1992). Elucidating the vascular response to burns with a new rat model. J. Trauma, 32(5), 557-563.

15. Горальський, Л. П., Хомич, В.Т., \& Кононський, О. І. (2011). Основи гістологічної техніки і морфофункиіональні методи досліджень у нормі та при патології. Житомир: Полісся.

16. Гунас, I. В., Яковлєва, О. О., \& Очеретнюк, А. О. (2012). Корекція гістологічних змін в легенях щурів при застосуванні інфузійного розчину HAES-LX-5 \% в перші 7 діб після опіку шкіри. Свim медицини та біологїі, 4, 73-76.

17. Макарова, О. І. (2014). Динамічні особливості гістологічних змін в легенях щурів у віддалений період після термічного опіку шкіри за умов його корекції інфузійним розчином HAES-LX-5 \%. Актуальные проблемы транспортной медицины, 4(2), 75-84.

18. Очеретнюк, А. О., Гунас, І. В., Небесна, 3. М., Паламарчук, О. В., \& Прокопенко, С. В. (2013). Ультраструктурний стан респіраторного відділу легень в ранні терміни після експериментальної термічної травми за умов застосування інфузійного розчину HAES-LX-5\%. Украйнський морфологічний альманах, 2(11), 77-79.

19. Гумінський, Ю. Й., \& Очеретна, Н. П. (2013). Динаміка морфологічних змін в селезінці щурів у ранні терміни після опіку шкіри 2-3 ступеня площею 21-23 \% поверхні шкіри та їх корекція інфузійним розчином HAES-LX-5 \%. Biomedical and biosocial anthropology, 22, 194-199.

20. Булько, І. В. (2016). Структурні зміни в селезінці щурів у пізніх стадіях опікової травми після корекції інфузійним розчином HAES-LX-5 \%. Вісник проблем біології і медицини, 2(1), 360-363.

21. Маліков, О.В. (2015). Структурні зміни мозкової речовини нирки щурів при експериментальній опіковій травмі шкіри за умов застосування інфузії HAES-LX-5\%. Вісник проблем біології $i$ медииини, 3(1), 309-314. 